\title{
Can Right Whales Out-Swim Climate Change? Can We?
}

\author{
By Andrew J. Pershing and Daniel E. Pendleton
}

\begin{abstract}
The article by Meyer-Gutbrod and colleagues in this issue demonstrates that the endangered North Atlantic right whale's preferred prey has declined as the Northwest Atlantic has warmed. Right whales are now spending more time foraging in historically colder habitats, but they are producing fewer calves. The low calf production could reflect a delay between the decline in the potential productivity of their traditional habitats and its increase in their new habitats. This delay would result in a "climate deficit" in their fitness. Right whales must also learn to forage successfully in their new habitats, creating an additional loss of fitness termed an "adaptation deficit." Humans will also face unavoidable climate deficits, but we have more options for minimizing adaptation deficits.
\end{abstract}

The North Atlantic right whale (Eubalaena glacialis) is a large, highly mobile predator. Within a week, these animals can swim hundreds of miles in search of dense patches of tiny crustaceans called copepods (especially, Calanus finmarchicus). As the new study by Meyer-Gutbrod et al. (2021, in this issue) shows, warming in the Gulf of Maine has caused a decline in C. finmarchicus abundance in the critical summer-fall feeding period. As a result, the 350 or so remaining right whales (Pettis et al., 2021) are spending less time in the Gulf of Maine during the summer and more time in the Gulf of St. Lawrence (Figure 1a).

In many ways, this story is simple. As waters warm, species move to track the conditions (both physical and biological) that they need to survive (Pinsky et al., 2013). For plankton like C. finmarchicus or slow animals like lobsters, this "tracking" is caused by differences in reproduction and survival across a gradient of condi- tions (Le Bris et al., 2018). Large animals like right whales can actively seek out their preferred conditions.

But, the right whale's specific story is not simple, and there are many parallels between right whales and people as we both struggle to adapt to climate change. Right whales require vast amounts of food to survive and reproduce. When C. finmarchicus is abundant in the Gulf of Maine, as it was prior to the 2010 regime shift identified by Meyer-Gutbrod and colleagues, female right whales are more likely to produce calves (Meyer-Gutbrod and Greene, 2014, 2018). However, when C. finmarchicus is scarce, as it was in the 1990s, the calving rate declines (MeyerGutbrod and Greene, 2014). Changes in the mean abundance of copepods also determines the movement of whales between feeding grounds within the Gulf of Maine (Pendleton et al., 2009), and now, the northward shift into the Gulf of

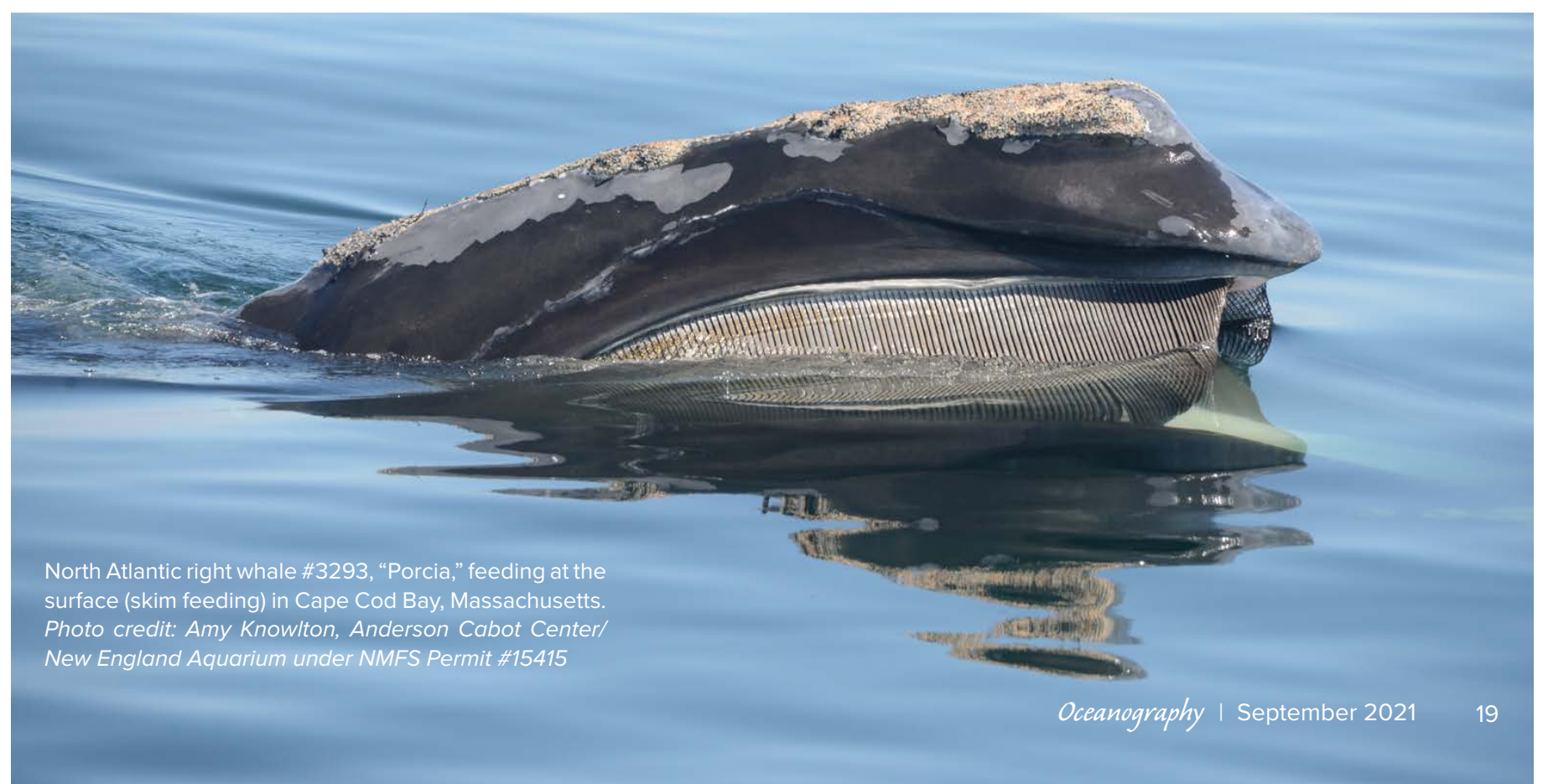




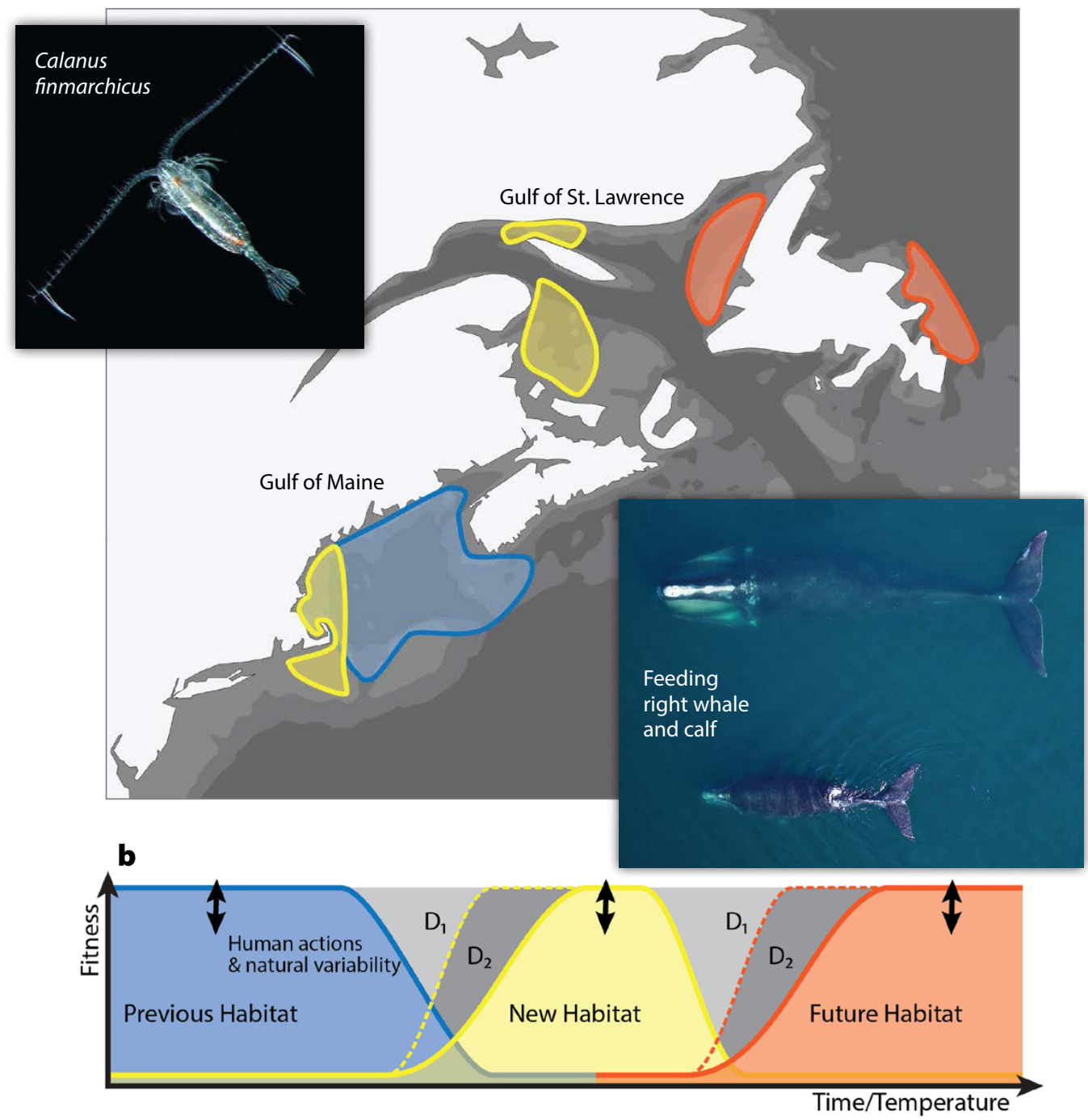

FIGURE 1. Progression of right whale habitats. (a) Map of the Northwest Atlantic showing the historical critical habitat for right whales (blue shading) and the feeding areas discussed in Meyer-Gutbrod et al. (2021, in this issue) and Pendleton et al. (2009) (yellow). Note that whales are moving continually through this region. Orange areas are speculative future areas in a warmer ocean. (b) Fitness of an organism affected by a climatedriven shift in habitat. Dashed lines are the potential of the habitat, solid lines and shading are the realized fitness. The light gray areas labeled $D_{1}$ indicate periods of "climate deficit"the loss in fitness between when the original habitat begins to decline and when the new habitat reaches its full potential. The dark gray areas $\left(D_{2}\right)$ indicate periods of "adaptation deficit" - the further loss of fitness as the organism becomes accustomed to the new habitat. Fitness in each habitat is not necessarily equal and will vary due to natural processes and human actions (black arrows). Photo of Calanus finmarchicus provided by $R$. Hopcroft, University of Alaska at Fairbanks. Photo of right whale and calf from Cape Cod Bay provided by M. Moore, Woods Hole Oceanographic Institution, authorized by Research Permit \#21371 issued by the National Marine Fisheries Service

St. Lawrence (Record et al., 2019; MeyerGutbrod et al., 2021, in this issue).

While a high average biomass of C. finmarchicus in a region is necessary for right whales, it is not sufficient. Right whales require copepods to be packaged into aggregations that are orders of magnitude more dense than background concentrations (Mayo and Marx, 1990). The Gulf of Maine's complex bathymetry and strong tides create convergent features that compress plankton into dense patches (Wishner et al., 1995; Pershing and Stamieszkin, 2020). Over generations, right whales have learned when and where to find both the high background biomass of $C$. finmarchicus and the physical conditions that create dense patches (Kenney et al., 2001).

Warming has now reduced the biomass of C. finmarchicus in the Gulf of Maine, and the whales have done the expected thing: move to the north where their cold-water prey are presumably more abundant. So far, this has not been a successful move. From 2012 to 2020, right whales averaged only 10.1 calves per year, with no calves born in 2018 (Pettis et al., 2021). Under these conditions, the right whale population can only grow if there are no deaths from ship strikes or from entanglements in fishing ropes (Corkeron et al., 2018; Meyer-Gutbrod and Greene, 2018). Sublethal entanglements make it harder for right whales to grow, potentially contributing to lower reproductive success (Stewart et al., 2021). Humans now have a strong influence on the potential fitness in a habitat (black arrows in Figure $1 b$ ), and unanticipated shifts in the whales' habitat preferences challenge the effectiveness of conservation measures (Davies and Brillant, 2019; Record et al., 2019; Meyer-Gutbrod et al., 2021).

While right whales have done the rational thing and shifted to the north, their shockingly low calving rate suggests that they are not finding what they need in their new habitats. C. finmarchicus is abundant in the Gulf of St. Lawrence (Brennan et al., 2019); however, it is possible that this region may not have reached its full potential as C. finmarchicus habitat. This would create a period of time when the potential fitness of a whale feeding in both its old and new habitats is suboptimal. We call the loss of fitness in the transition period a "climate deficit" (regions $\mathrm{D}_{1}$ in Figure $1 \mathrm{~b}$ ).

Another possibility is that the whales 
have yet to figure out where and when to find the high-density patches that they need. Climate change is forcing them to learn how to make a living in a new part of the ocean. This is a hard challenge that humans have made even harder. Ungulates on land learn to migrate from older members of the population (Jesmer et al., 2018), and whales may use a similar process to learn how to forage successfully. This means that their ability to find patches of copepods is degraded by their small population size. It is likely that the 5,000-10,000 right whales that were swimming around a few centuries ago (Reeves et al., 2007) would have been able to solve the puzzle of the Gulf of St. Lawrence faster than today's few hundred whales. It is also likely that the current population could solve the puzzle faster if they could communicate with one another without competition from ships and other noisy human activities (Hatch et al., 2012). We term the loss of fitness as an animal learns how to live in a new habitat the "adaptation deficit" (regions $\mathrm{D}_{2}$ in Figure 1b). But, even if the whales figure out that the Gulf of St. Lawrence is suitable habitat, the insidious nature of climate change means that they will likely have to move again in a few decades (to the orange regions in Figure 1) and go through another period of reduced fitness.

Much like right whales, humans have come to expect certain things from the environment, expectations that are shaped by personal experience and cultural history. Where we farm and fish, and the locations of the communities and infrastructure that support those activities, reflects past experiences. We must now confront the challenge of adapting these activities to a rapidly changing climate (Pershing et al., 2019). We will no doubt incur both climate and adaptation deficits in our economic, social, and potentially biological fitness. Just like the whales who have moved and will likely have to keep moving, our climate change adaptation will be an ongoing process. Just as the whales are struggling to learn to forage in a new environment, there will be costs to every adaptive step we take. Finally, just as the challenge facing whales is compounded by their low numbers, our adaptation challenges will be easier if we work together. @

\section{REFERENCES}

Brennan, C.E., F. Maps, W.C. Gentleman, S. Plourde, D. Lavoie, J. Chassé, C. Lehoux, K.A. Krumhansl, and C.L. Johnson. 2019. How transport shapes copepod distributions in relation to whale feeding habitat: Demonstration of a new modelling framework. Progress in Oceanography 171:1-21, https://doi.org/10.1016/j.pocean.2018.12.005.

Corkeron, P., P. Hamilton, J. Bannister, P. Best, C. Charlton, K.R. Groch, K. Findlay, V. Rowntree, E. Vermeulen, and R.M. Pace III. 2018. The recovery of North Atlantic right whales, Eubalaena glacialis, has been constrained by human-caused mortality. Royal Society Open Science 5(11):180892, https://doi.org/10.1098/rsos.180892.

Davies, K.T.A., and S.W. Brillant. 2019. Mass humancaused mortality spurs federal action to protect endangered North Atlantic right whales in Canada. Marine Policy 104:157-162, https://doi.org/10.1016/ j.marpol.2019.02.019.

Hatch, L.T., C.W. Clark, S.M. Van Parijs, A.S. Frankel, and D.W. Ponirakis. 2012. Quantifying loss of acoustic communication space for right whales in and around a U.S. National Marine Sanctuary. Conservation Biology 26(6):983-994, https://doi.org/10.1111/j.1523-1739.2012.01908.x.

Jesmer, B.R., J.A. Merkle, J.R. Goheen, E.O. Aikens, J.L. Beck, A.B. Courtemanch, M.A. Hurley, D.E. McWhirter, H.M. Miyasaki, K.L. Monteith, and others. 2018. Is ungulate migration culturally transmitted? Evidence of social learning from translocated animals. Science 361(6406):1023, https://doi.org/10.1126/science.aat0985.

Kenney, R.D., C.A. Mayo, and H.E. Winn. 2001. Migration and foraging strategies at varying spatial scales in western North Atlantic right whales. Journal of Cetacean Research and Management Special Issue 2:251, https://doi.org/10.47536/ jcrm.vi.283.

Le Bris, A., K.E. Mills, R.A. Wahle, Y. Chen, M.A. Alexander, A. Allyn, J. Scheutz, J.D. Scott, and A.J. Pershing. 2018. Climate vulnerability and resilience in the most valuable North American fishery. Proceedings of the National Academy of Sciences of the United States of America 115(8):1,831-1,836, https://doi.org/10.1073/pnas.1711122115.

Mayo, C.A., and M.K. Marx. 1990. Surface foraging behavior of the North Atlantic right whale, Eubalaena Glacialis, and associated zooplankton characteristics. Canadian Journal of Zoology-Revue Canadienne De Zoologie 68(10):2,214-2,220, https://doi.org/ 10.1139/z90-308.

Meyer-Gutbrod, E.L., and C.H. Greene. 2014. Climate-associated regime shifts drive decadalscale variability in recovery of North Atlantic right whale population. Oceanography 27(3):148-153, https://doi.org/10.5670/oceanog.2014.64.

Meyer-Gutbrod, E.L., and C.H. Greene. 2018. Uncertain recovery of the North Atlantic right whale in a changing ocean. Global Change Biology 24(1):455-464, https://doi.org/10.1111/ gcb.13929.

Meyer-Gutbrod, E.L., C.H. Greene, K.T.A. Davies, and D.G. Johns. 2021. Ocean regime shift is driving collapse of the North Atlantic right whale population. Oceanography 34(3):22-31, https://doi.org/ 10.5670/oceanog.2021.308.
Pendleton, D.E., A.J. Pershing, M.W. Brown, C.A. Mayo, R.D. Kenney, N.R. Record, and T.V.N. Cole. 2009. Regional scale mean matters: Mean copepod concentration indicates relative abundance of North Atlantic right whales. Marine Ecology-Progress Series 378:211-225, https://doi.org/10.3354/ meps07832.

Pershing, A.J., N.R. Record, B.S. Franklin, B.T. Kennedy, L. McClenachan, K.E. Mills, J.D. Scott, A.C. Thomas, and N.H. Wolff. 2019. Challenges to natural and human communities from surprising ocean temperatures. Proceedings of the National Academy of Sciences of the United States of America 116(37):18,378-18,383, https://doi.org/ 10.1073/pnas.1901084116.

Pershing, A.J., and K. Stamieszkin. 2020. The North Atlantic ecosystem, from plankton to whales. Annual Review of Marine Science 12:339-359, https://doi.org/10.1146/ annurev-marine-010419-010752.

Pettis, H.M., R.M. Pace III, and P.K. Hamilton. 2021. North Atlantic Right Whale Consortium 2020 Annual Report Card. Report to the North Atlantic Right Whale Consortium, 22 pp.

Pinsky, M.L., B. Worm, M.J. Fogarty, J.L. Sarmiento, and S.A. Levin. 2013. Marine taxa track local climate velocities. Science 341(6151):1,239-1,242, https://doi.org/10.1126/science.1239352.

Record, N.R., J.A. Runge, D.E. Pendleton, W.M. Balch, K.T.A. Davies, A.J. Pershing, C.L. Johnson, K. Stamieszkin, R. Ji, Z. Feng, and others. 2019. Rapid climate-driven circulation changes threaten conservation of endangered North Atlantic right whales. Oceanography 32(2):162-169, https://doi.org/10.5670/oceanog.2019.201.

Reeves, R.R., T.D. Smith, and E.A. Josephson. 2007. Near-annihilation of a species: Right whaling in the North Atlantic. Pp. 39-74 in The Urban Whale. S.D. Kraus, and R.M. Rolland, eds, Harvard University Press, Cambridge, MA, USA.

Stewart, J.D., J.W. Durban, A.R. Knowlton, M.S. Lynn, H. Fearnbach, J. Barbaro, W.L. Perryman, C.A. Miller, and M.J. Moore. 2021. Decreasing body lengths in North Atlantic right whales. Current Biology 31(14):3,174-3,179.E3, https://doi.org/ 10.1016/j.cub.2021.04.067.

Wishner, K.F., J.R. Schoenherr, R. Beardsley, and C.S. Chen. 1995. Abundance, distribution and population structure of the copepod Calanus finmarchicus in a springtime right whale feeding area in the southwestern Gulf of Maine. Continental Shelf Research 15(4-5):475-507, https://doi.org/ 10.1016/0278-4343(94)00057-T.

\section{AUTHORS}

Andrew J. Pershing (apershing@climatecentral.org) is Director of Climate Science, Climate Central Inc., Princeton, NJ, USA. Daniel E. Pendleton is Research Scientist, Anderson Cabot Center for Ocean Life at the New England Aquarium, Boston, MA, USA.

\section{ARTICLE CITATION}

Pershing, A.J., and D.E. Pendleton. 2021. Can right whales out-swim climate change? Can we? Oceanography 34(3):19-21, https://doi.org/10.5670/ oceanog.2021.315.

\section{COPYRIGHT \& USACE}

This is an open access article made available under the terms of the Creative Commons Attribution 4.0 International License (https://creativecommons.org/ licenses/by/4.0/), which permits use, sharing, adaptation, distribution, and reproduction in any medium or format as long as users cite the materials appropriately, provide a link to the Creative Commons license, and indicate the changes that were made to the original content. 